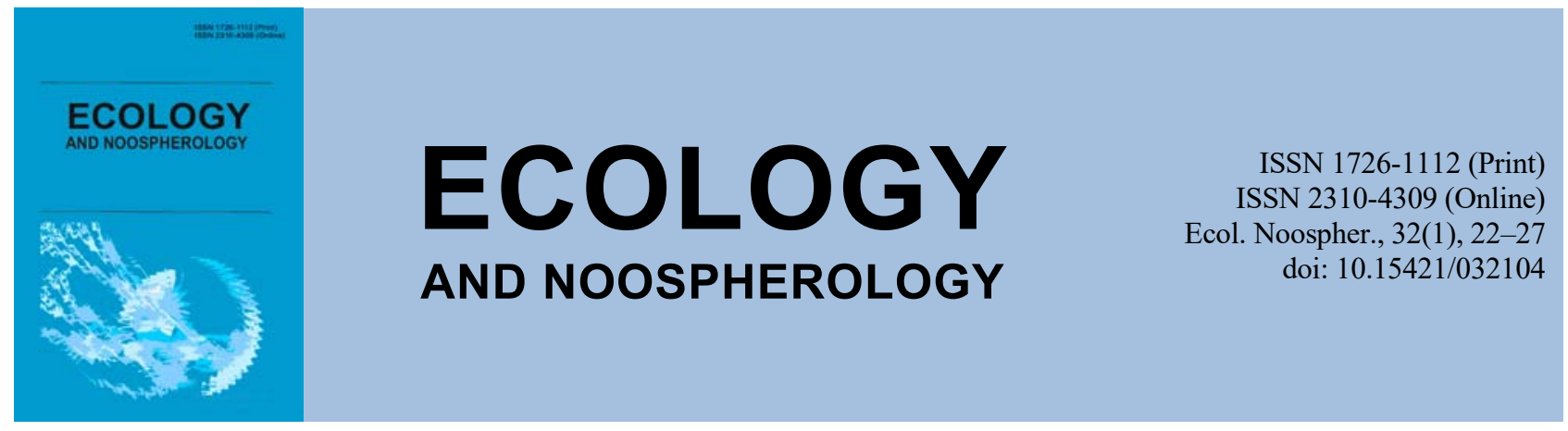

\title{
Evaluation of the influence of heavy metals on the degree of damage Cameraria ohridella Deschka \& Dimič, 1986 leaf surface of Aesculus hippocastanum Linnaeus, 1753
}

\author{
O. V. Seliutina, K. K. Holoborodko
}

Oles Honchar Dnipro National University, Dnipro, Ukraine

Article info

Received 10.05.2021

Received in revised form 22.05.2021

Accepted 11.06.2021

Oles Honchar Dnipro

National University,

Gagarin Ave., 72, Dnipro, 49010, Ukraine.

Tel.: +38066-795-63-20

E-mail: goloborodko@ua.fm
Seliutina, O. V., Holoborodko, K. K. (2021). Evaluation of the influence of heavy metals on the degree of damage Cameraria ohridella Deschka \& Dimič, 1986 leaf surface of Aesculus hippocastanum Linnaeus, 1753. Ecology and Noospherology, 32(1), 22-27. doi:10.15421/032104

The work presents the results of research on effect of heavy metals $(\mathrm{Zn}, \mathrm{Cu}, \mathrm{Pb}, \mathrm{Cd})$ on degree of horse chestnut (Aesculus hippocastanum Linnaeus, 1753) leaf surface damage by chestnut miner (Cameraria ohridella Deschka \& Dimič, 1986) caterpillars. Analysis of leaf blade damage of the forage plant species by $C$. ohridella was conducted for four years (2017-2021). The research covered all the main park urban ecosystems in Dnipro city where horse chestnut trees were planted. Monitoring was carried out during the three summer months, which corresponds to the main feeding period of the three most active $C$. ohridella generations (I, II, and III). About 96 samples were used and prepared for atomic absorption analysis to study the content of heavy metals in A. hippocastanum leaf blades. On the territory of the park ecosystems in Dnipro city, eight groups of model horse chestnut trees of 20-30 years of age were identified which have similar morphological and taxonomic features but different degrees of leaf damage by C. ohridella miner. Since the plantations of horse chestnut are mainly located in an urban environment, we conducted research to test the hypothesis about the influence of heavy metals on C. ohridella vital activity. Presumably, the content of heavy metals also affects the degree of leaf blade damage. In this regard, we conducted research on the content of heavy metals in A. hippocastanum leaf tissues. It was found that accumulation in the horse chestnut leaf tissues of four basic heavy metals $(\mathrm{Zn}, \mathrm{Cu}, \mathrm{Pb}, \mathrm{Cd})$ contained in all urban environments depends on the orographic features of the area where $A$. hippocastanum trees grow. It also was found that the higher in relief were located the horse chestnut plantings, the greater the percentage of their invasion by the miner, and this trend was observed during the three summer months. For example, in the Manuylivsky Park where horse chestnut trees are located at $56 \mathrm{~m}$ above sea level, the average leaf invasion by the miner in August is $14 \%$; in the same month in Oles Honchar Dnipro National University Botanical Garden (149 m), the level of invasion was 78\%. Research on the effects of heavy metals on $C$. ohridella populations also showed significant differences by the types of urban ecosystems. It was found that the higher content of heavy metals in the leaf tissues in a forage plant, the greater percentage of their surface damage by mines.

Keywords: impact of invasive species; Cameraria ohridella; Aesculus hippocastanum sustainability; urban park ecosystems; urban environment

\section{Оцінка впливу важких металів на ступінь пошкодження Cameraria ohridella Deschka \& Dimič, 1986 листкової поверхні Aesculus hippocastanum Linnaeus, 1753}

\author{
О. В. Селютіна, К. К. Голобородько
}

Дніпровський національний університет імені Олеся Гончара, Дніпро, Україна 
У статті представлено результати дослідження впливу важких металів ( $\mathrm{Zn}, \mathrm{Cu}, \mathrm{Pb}, \mathrm{Cd})$ на ступінь пошкодження гусінню каштанового мінера (Cameraria ohridella Deschka \& Dimič, 1986) листкових поверхонь гіркокаштану звичайного (Aesculus hippocastanum Linnaeus, 1753). Установлено залежність між кількістю мін C. ohridella на листку та концентрацією важких металів у тканинах кормової рослини гусені. У паркових урбоекосистемах із найбільшою концентрацією важких металів у тканинах листків A. hippocastanum виявилась найбільша кількість мін на листку.

Ключові слова: вплив інвазійних видів; Cameraria ohridella; стійкість Aesculus hippocastanum; паркові урбоекосистеми; міське середовище

\section{Вступ}

Біологічні інвазії чужорідних видів на міських об'єктах озеленення можна віднести до екологічних катастроф. Проникаючи на нову територію із сприятливими умовами, такі види за відсутності природних ворогів швидко збільшують свою чисельність і безперешкодно поширюються міськими насадженнями (Percival et al., 2011; Jagillo et al., 2019; Seliutina et al., 2020). У цілому для захисту дерев Aesculus Linnaeus, 1753 від C. ohridella в Європі виділяються значні кошти (War et al., 2018).

На більшій частині нового ареалу каштановий мінер характеризується популяційною щільністю (Augustin et al., 2008). Це обумовлює статус не тільки фонового, а й масового виду, що пов'язано 3 високим рівнем пошкодження кормових рослин (Szaboky et al., 1997; Augustin et al., 2008). Популяції мінера 3 Балкан i Центральної Європи в основному продукують три генерації протягом одного сезону (Deschka, Dimič, 1986; Augustin et al., 2004). У Центральній Свропі імаго першої генерації з'являється в травні, другої в червні і третьої у вересні (Pschorn-Walcher, 1994; Straw et al., 2004). Імаго першої генерації активний близько одного місяця, що синхронізовано 3 цвітінням гіркокаштана звичайного (Dimič et al., 1986). В Свропі каштановий мінер може розвиватися в III-V генераціях 3 експоненціальним збільшенням чисельності від генерації до генерації (Skuhravy et al., 1998; Behmer, 2009).

В умовах міста Дніпро (Holoborodko et al., 2009, 2018; Shupranova et al., 2019) щорічно реєструється розвиток 4 генерацій. Вихід імаго першої спостерігається в останній декаді квітня, останньої генерації - наприкінці жовтня початку листопада. Термін розвитку окремої генерації в умовах міста Дніпро триває від 65 до 110 діб. Це призводить до неконтрольованої інвазії, що проявляється в ураженні більш ніж 70-80 \% асимілятивної поверхні листової пластинки гіркокаштана звичайного. Продовження такої інвазії протягом 3-4 років знесилюють дерева A. hippocastanum та призводять до його загибелі (Holoborodko et al., 2016).

При дослідженні впливів параметрів оточуючого середовища на популяції C. ohridella було встановлено (Tarwacki et al., 2012), що саме мікрокліматичні особливості найбільше впливають на особливості заселення інвайдером нових територій. $\mathrm{y}$ більш посушливих і загазованих умовах рослини гіркокаштана звичайного є більш пошкодженими (Jagillo et al., 2017). При цьому залишається майже не дослідженим вплив важких металів на особливості поширення цього інвазійного виду.

Метою нашого дослідження було здійснити оцінку впливу важких металів на ступінь пошкодження C. ohridella листкових поверхонь A. hippocastanum у різних умовах міського середовища.

\section{Матеріали та методи досліджень}

Аналіз ушкодження листкових пластинок кормової рослини C. ohridella проводили протягом чотирьох років (2017-2021 рр.) візуально за модифікованою шкалою, запропонованою М. Д. Зеровою та ін. (Zerova et al., 2007). Дослідженнями було охоплено всі основні паркові урбоекосистеми м. Дніпро, де висаджено дерева гіркокаштана (рис. 1). Моніторинг здійснювався протягом трьох літніх місяців, що відповідає основному періоду живлення трьох найактивніших генерацій $C$. ohridella (I, II Ta III).

Для дослідження вмісту важких металів у листкових пластинках $A$. hippocastanum методом атомноабсорбційного аналізу було використано і підготовлено близько 96 проб. Дослідний матеріал було відібрано у восьми паркових зонах міста Дніпро: сквер Металургів, парк Мануйлівський, парк імені Т. Г. Шевченка, парк Дружби народів, парк імені Л. Глоби, парк Молодіжний, Ботанічний сад ДНУ імені Олеся Гончара, парк Придніпровський. В них були виділені вісім груп модельних дерев гіркокаштана звичайного 20-30-річного віку із близькими морфолого-таксаційними ознаками, але 3 різним ступенем ураженості листків мінером $C$. ohridella.

Листки середньої формації по 5 штук відбирали на річному вегетативному прирості 3 нижньої третини крони південної експозиції в суху ясну погоду в середині липня 2018 року від п'яти дерев гіркокаштана звичайного одночасно з кожної дослідної ділянки (всього досліджено 40 дерев).

Листкові пластинки A. hippocastanum дегідратували у фарфорових тиглях за допомогою сушильної шафи при $\mathrm{t}^{\circ}=100^{\circ}$ C. Електронними вагами AXIS AD500 сухий залишок листків гіркокаштана звичайного зважували 3 точністю до 0,001 г (необхідна маса для аналізу становила $0,5-1,0$ г). Потім у муфельній печі при $\mathrm{t}^{\circ}=450^{\circ} \mathrm{C}$ проводили зоління. Золу насипали до конічної колби та додавали 0,5 мл концентрованої азотної кислоти та 0,5 мл бідистильованої води. Отриманий розчин доводили до 10 мл дистиляту та фільтрували за допомогою беззольних фільтрів, далі промивали тигель 10 мл бідистильованої води та доводили об'єм розчину до 25 мл. У пробах аналізувався вміст таких елементів, як $\mathrm{Zn}, \mathrm{Cu}, \mathrm{Pb}, \mathrm{Cd}$.

Уміст важких металів у листкових пластинках A. hippocastanum визначали 3 використанням методу атомно-абсорбційної спектрофотометрії на спектрофотометрі AAS-30 за стандартною методикою I. П. Хавезова (1983). Результати розраховували за формулою:

$$
\mathrm{C}_{0}=\mathrm{C}_{1} \times \mathrm{V} / \mathrm{P},
$$

де $\mathrm{C}_{0}-$ показник вмісту важких металів у листкових пластинках A. hippocastanum, мг/кг сухої маси;

$\mathrm{C}_{1}$ - концентрація металу в 1 мл розчину (мкг/мл);

$\mathrm{V}$ - об'єм розчину, мл;

P - маса наважки листкових пластинок гіркокаштана (суха маса), г.

Отримані дані аналізували за допомогою програми Statistica (версія 8, StatSoft, США). Оскільки в місті не було знайдено абсолютно непошкодженого C. ohridella дерев гіркокаштана звичайного, за контроль взято насадження 3 низьким $(8,67 \%)$ ураженням рослин мінером.

\section{Результати та їх обговорення}

Оскільки насадження гіркокаштана звичайного знаходяться переважно у міському середовищі, нами були здійснені дослідження з перевірки гіпотези про вплив важких металів на життєдіяльність C. ohridella. Імовірно вміст важких металів впливає й на ступінь ураження листкової пластинки. Для цього ми провели дослідження вмісту важких металів у тканинах листків A. hippocastanum (табл. 1). 


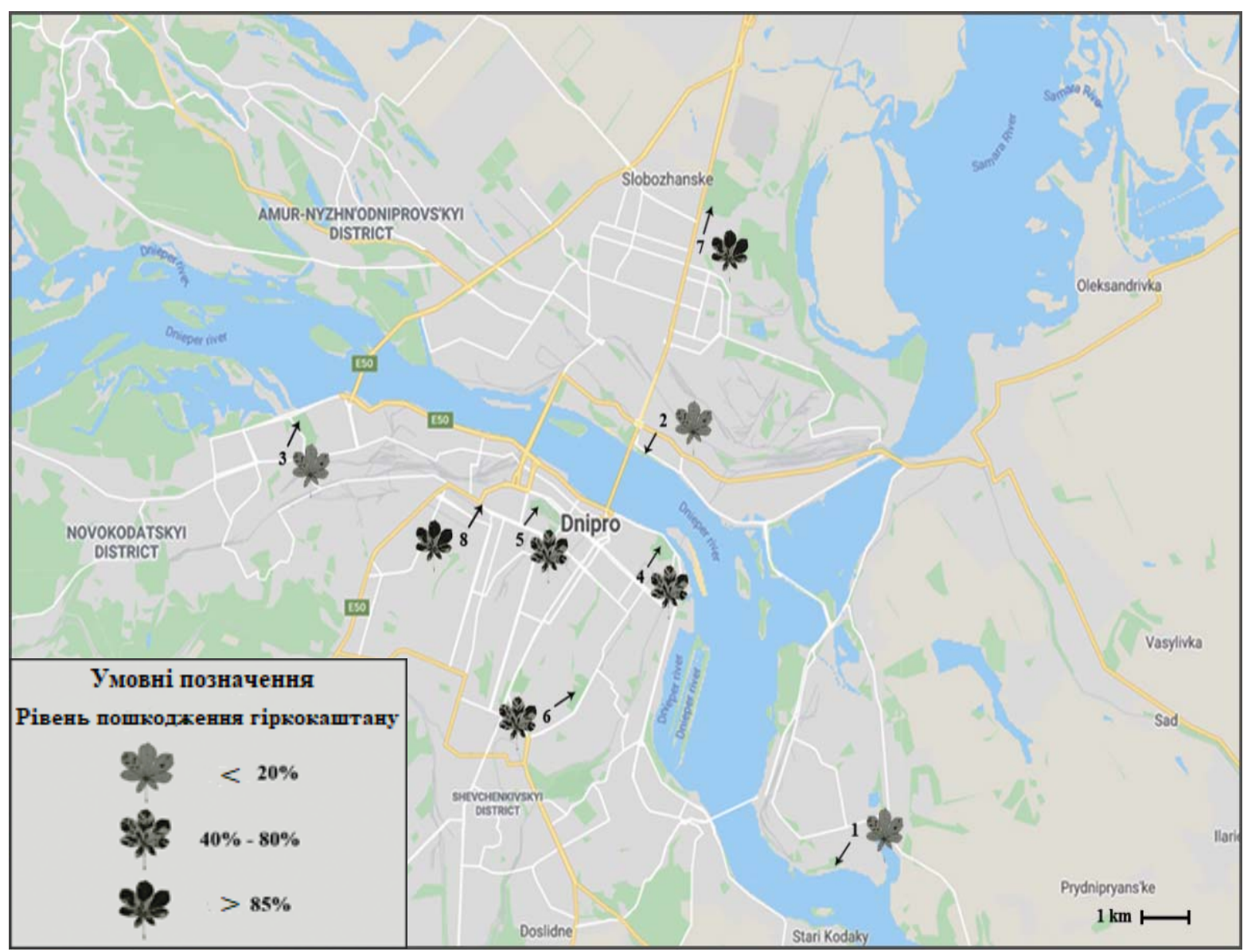

Рис. 1. Насадження гіркокаштана звичайного на території м. Дніпро, в межах яких проводили збір матеріалу та обліки: 1 - парк Придніпровський; 2 - парк Мануйлівський; 3 - парк Молодіжний; 4 - парк ім. Т. Г. Шевченка; 5 - парк ім. Л. Глоби; 6 - Ботанічний сад ДНУ; 7 - парк Дружби народів; 8 - сквер Металургів

Таблиця 1

Описові статистики вмісту важких металів у тканинах листків $A$. hippocastanum (у мкг/г, середнє \pm ст. помилка, $\mathrm{N}=9$ )

\begin{tabular}{lcccc}
\hline \multicolumn{1}{c}{ Біогеоценоз } & \multicolumn{4}{c}{ Важкі метали } \\
\cline { 2 - 5 } & $\mathrm{Zn}$ & $\mathrm{Cu}$ & $\mathrm{Pb}$ & $\mathrm{Cd}$ \\
\hline Сквер Металургів & $26,56 \pm 0,59$ & $6,10 \pm 0,19$ & $11,16 \pm 0,32$ & $0,44 \pm 0,014$ \\
Парк Мануйлівський & $22,52 \pm 0,73$ & $3,65 \pm 0,12$ & $8,28 \pm 0,26$ & $0,33 \pm 0,010$ \\
Парк ім. Т. Г. Шевченка & $28,33 \pm 0,69$ & $5,87 \pm 0,15$ & $10,19 \pm 0,26$ & $0,43 \pm 0,006$ \\
Парк Дружби народів & $29,91 \pm 0,70$ & $8,07 \pm 0,23$ & $9,36 \pm 0,33$ & $0,32 \pm 0,009$ \\
Парк ім. Л. Глоби & $23,68 \pm 0,53$ & $3,78 \pm 0,11$ & $9,66 \pm 0,29$ & $0,42 \pm 0,014$ \\
Парк Молодіжний & $21,55 \pm 0,84$ & $5,80 \pm 0,20$ & $9,58 \pm 0,27$ & $0,40 \pm 0,012$ \\
Ботсад ДНУ & $34,57 \pm 0,97$ & $7,36 \pm 0,21$ & $12,09 \pm 0,19$ & $0,51 \pm 0,013$ \\
Парк Придніпровський & $23,58 \pm 0,64$ & $4,46 \pm 0,29$ & $10,36 \pm 0,32$ & $0,41 \pm 0,009$ \\
\hline У цілому & $26,34 \pm 0,55$ & $5,64 \pm 0,19$ & $10,08 \pm 0,16$ & $0,41 \pm 0,008$ \\
\hline
\end{tabular}

Виявилось, що накопичення у тканинах листків гіркокаштана звичайного чотирьох основних важких металів ( $\mathrm{Zn}, \mathrm{Cu}, \mathrm{Pb}, \mathrm{Cd})$, що перебувають у всіх урбосередовищах, залежить від орографічних особливостей місцевості, де ростуть дерева $A$. hippocastanum. На рис. 2 бачимо, що чим вище за рельєфом знаходиться насадження гіркокаштана звичайного, тим вищий уміст цинку, міді, свинцю та кадмію в тканинах його листків.

За таких особливостей накопичення важких металів у тканинах гіркокаштана звичайного були проведені дослідження 3 виявлення впливу вмісту важких металів на ступінь ушкодження листових поверхонь каштановим мінером (рис. 3).

Наші дослідження показують достовірну залежність ступеня ушкодження листкової пластинки від висоти над рівнем моря, на якій знаходиться паркова урбоекосистема, та вмісту важких металів у тканинах листка A. hippocastanum (табл. 2).

3'ясувалось, що чим вище за рельєфом розташовані насадження гіркокаштана звичайного, тим більший відсоток їх заселення, причому така тенденція спостерігалась всі три літніх місяці. Наприклад, у парку Мануйлівському насадження гіркокаштана розташовані на позначці 56 м над рівнем моря, середнє заселення листків у серпні становить 14 \%, у цей же місяць у Ботанічному саду ДНУ (149 м) рівень заселення становив $78 \%$.

Дослідження із впливу важких металів $(\mathrm{Zn}, \mathrm{Cu}, \mathrm{Pb}, \mathrm{Cd})$ на популяції $C$. ohridella також показали достовірні відмінності за типами урбоекосистем. Виявилось, що чим більший уміст важких металів у тканинах листків кормової рослини, тим більше відсоток ураження мінами їх поверхні. 

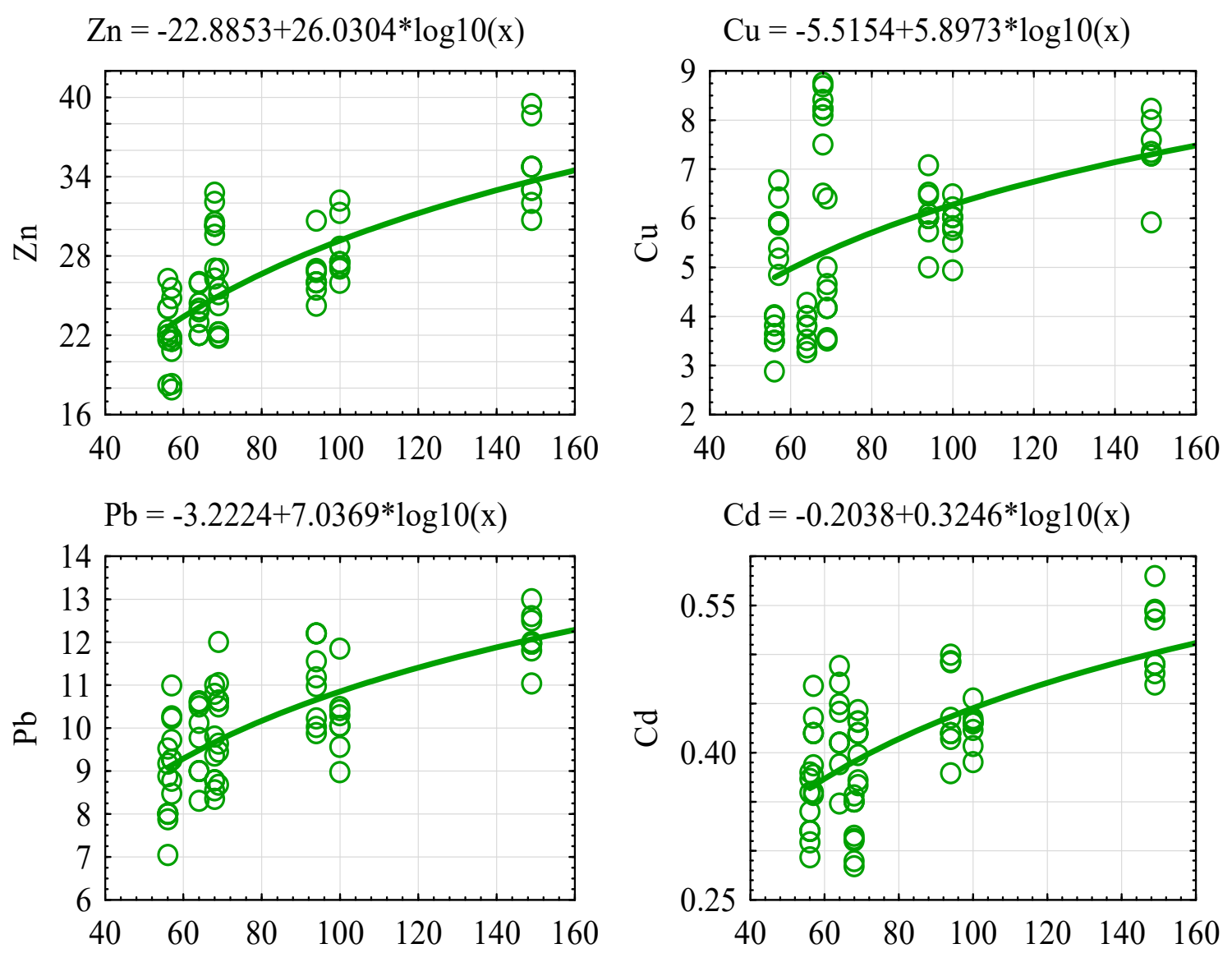

Рис. 2. Залежність концентрації важких металів у листках гіркокаштана звичайного (у мкг/г) від висоти рельєфу
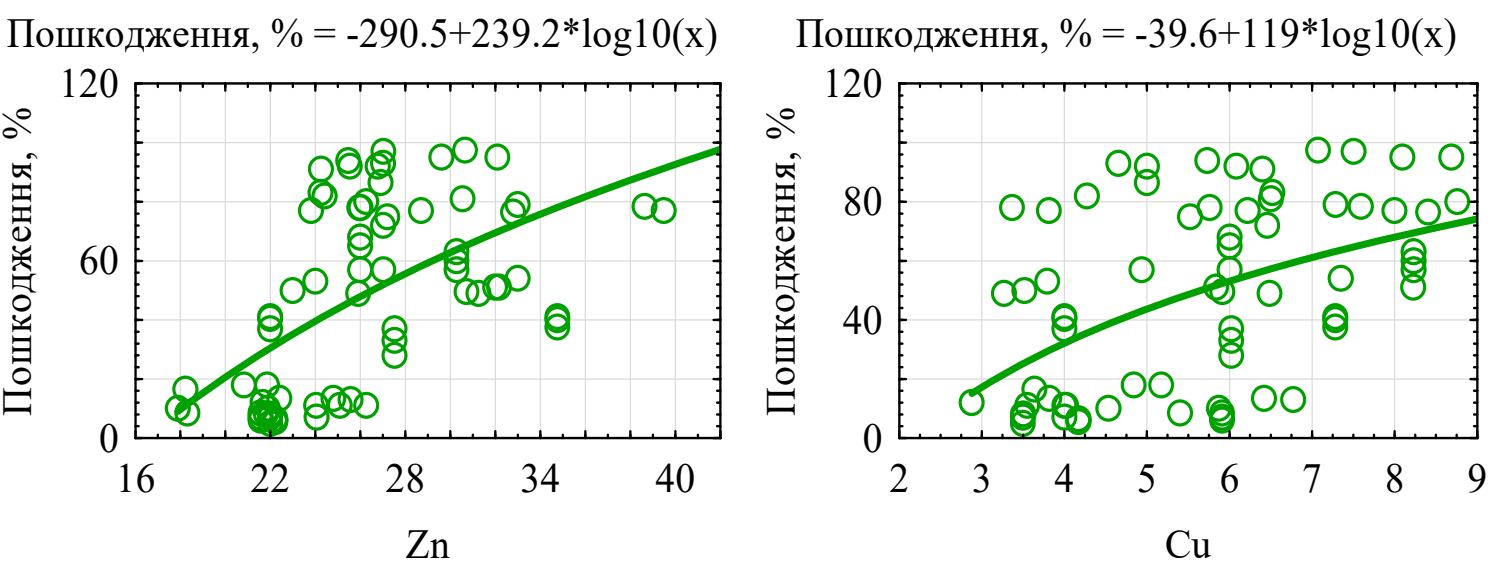

Пошкодження, $\%=-190+238 * \log 10(x)$

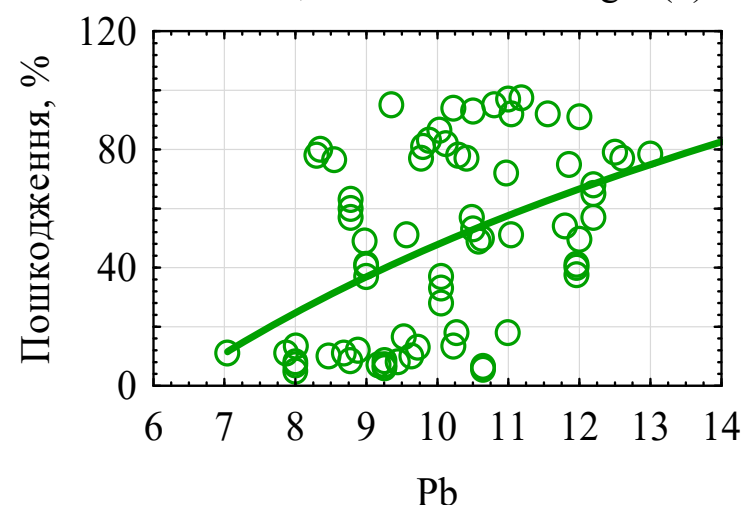

Пошкодження, $\%=63+41 * \log 10(x)$

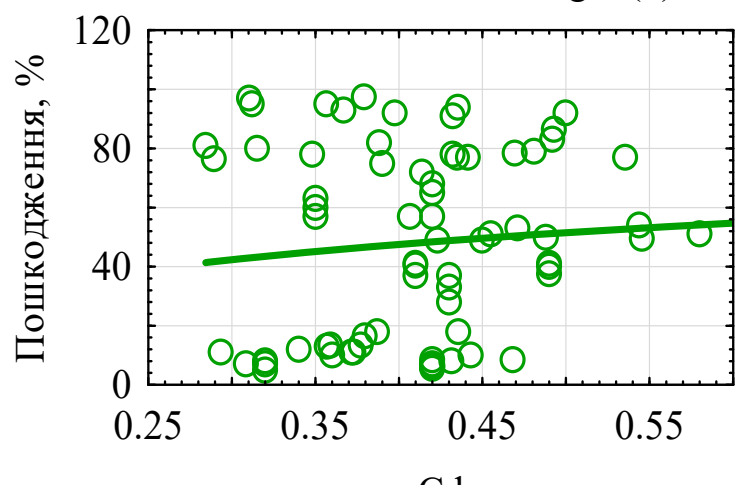

$\mathrm{Cd}$

Рис. 3. Залежність пошкодження листкової поверхні A. hippocastanum (вісь ординат, \%) від концентрації важких металів (вісь абсцис, мкг/г) 


\section{Таблиця 2}

Результати загальної лінійної моделі впливу вмісту важких металів, висоти рельєфу та місяця на пошкодження листових пластин $\left(R^{2} a d j=0.69, F=23.4, p<0.001\right)$

\begin{tabular}{lccccc}
\hline \multicolumn{1}{c}{ Вплив } & $\begin{array}{c}\text { Сума } \\
\text { квадратів }\end{array}$ & $\begin{array}{c}\text { Ступені } \\
\text { вольності }\end{array}$ & $\begin{array}{c}\text { Середня сума } \\
\text { квадратів }\end{array}$ & F-відношення & $p$-рівень \\
\hline Константа & 4272.2 & 1 & 4272.2 & 14.15 & $<0.001$ \\
$\mathrm{Zn}$ & 2961.6 & 1 & 2961.6 & 9.81 & $<0.001$ \\
$\mathrm{Cu}$ & 3335.8 & 1 & 3335.8 & 11.05 & $<0.001$ \\
$\mathrm{~Pb}$ & 2493.7 & 1 & 2493.7 & 8.26 & 0.01 \\
$\mathrm{Cd}$ & 33.7 & 1 & 33.7 & 0.11 & 0.74 \\
Висота рельєфу & 1441.3 & 1 & 1441.3 & 4.77 & 0.03 \\
Місяць & 11992.4 & 2 & 5996.2 & 19.86 & $<0.001$ \\
Помилка & 19318.6 & 64 & 301.9 & - & -
\end{tabular}

\section{Висновки}

3'ясовано достовірну залежність ступеня ушкодження листкової пластинки від висоти над рівнем моря, на якій знаходиться паркова урбоекосистема, та вмісту важких металів у тканинах листка $A$. hippocastanum. Чим вище за рельєфом розташовані насадження гіркокаштана звичайного, тим більший відсоток їх заселення, причому така тенденція спостерігалась всі три літніх місяці. Найнижчий показник у парку Мануйлівському, де насадження гіркокаштана розташовані на позначці 56 м над рівнем моря, середнє заселення листків у серпні становить $14 \%$, у цей же місяць у Ботанічному саду ДНУ (149 м) рівень заселення становив 78 \%. Установлено залежність між кількістю мін $C$. ohridella на листку та концентрацією важких металів ( $\mathrm{Zn}, \mathrm{Cu}, \mathrm{Pb}, \mathrm{Cd})$ у тканинах кормової рослини гусені. У паркових урбоекосистемах із найбільшою концентрацією важких металів у тканинах листків $A$. hippocastanum виявилась найбільша кількість мін на листку. Максимальні значення кількості мін на окремих листках $A$. hippocastanum сягали 450-465 шт.

\section{References}

Augustin, S., Guichard S., Svato, A., Gilbert M. (2004). Monitoring the regional spread of the invasive leafminer Cameraria ohridella (Lepidoptera: Gracillariidae) by damage assessment and pheromone trapping. Environmental Entomology. 33, 1584-1592.

Augustin, S., Guichard, S., Heitland, W., Freise, J., Svatoš, A., Gilbert, M. (2008). Monitoring and dispersal of the invading Gracillariidae Cameraria ohridella. Journal of Applied Entomology, 133(1), 58-66.

Behmer, S. T. (2009). Insect herbivore nutrient regulation. Annual Review Entomology, 54, 165-187.

Deschka, G., Dimič, N. (1986). Cameraria ohridella n. sp. Aus Mactdonien, Jugoslawien (Lepidoptera, Gracillaridae). Acta Entomologica Jugoslavica, 22(1), 11-23.

Holoborodko, K. K, Ryabka, K. O, Zaitseva, I. A, Kondratieva, K. V. (2009). Poshyrennya ta suchasnyy stan kashtanovoyi minuyuchoyi moli (Cameraria ohridella Deschka \& Dimič, 1986) u m. Dnipropetrovs'k [Distribution and current state of chestnut moth (Cameraria ohridella Deschka \& Dimič, 1986) in Dnepropetrovsk]. Problems of bioindication and ecology 14 (2): 163-168 (in Ukrainian).

Holoborodko, K. K., Rusynov, V. I., Seliutina, O. V. (2018). Invaziyni moli-strokatky (Gracillariidae Stainton, 1854) fauny Botanichnoho sadu Dniprovs'koho natsional'noho universytetu imeni Olesya Honchara [Invasive moths (Gracillariidae Stainton, 1854) of the fauna of the Botanical Garden of Oles Honchar Dnipro]. Issue of steppe forestry and forest reclamation of soils, 47, 87-91 (in Ukrainian).

Jagiełło, R., Baraniak, E., Karolewski, P., Łakomy, P., BehnkeBorowczyk, J., Walczak, U., Giertych M. J. (2017). Ecophysiological aspects of the interaction between Cameraria ohridella and Guignardia aesculi on Aesculus hippocastanum. Dendrobiology, 78, 146-156.

Jagiello, E., Baraniak, E., Guzicka, M., Karolewsk, P., Ukowski, A., Giertych M. J. (2019). One step closer to understanding the ecology of Cameraria ohridella (Lepidoptera: Gracillariidae): The effects of light conditions. European Journal of Entomology, 116, 42-51.

Percival, G. C., Barrow, I., Noviss, K., Keary, I., Pennington, P. (2011). The impact of horse chestnut leaf miner (Cameraria ohridella Deschka and Dimic) on vitality, growth and reproduction of Aesculus hippocastanum L. Urban For. Urban Green. 10. 11-17.

Pschorn-Walcher, H. (1994). Field biology of the introduced horse-chestnut leafminer Cameraria ohridella Deschka et Dimič (Lepidoptera: Gracillariidae) in theVienna Woods. Linzer Biol. Beitr. 26, 633-642.

Reinhardt, F, Herle, M, Bastiansen, F, Streit, B. (2003). Economic impact of the spread of alien species in Germany. Berlin, Germany: Federal Environmental Agency (Umweltbundesamt). 229 pp.

Seliutina, O. V., Shupranova, L. V., Holoborodko, K. K., Shulman, M. V., Bobylev, Y. P. (2020). Effect of Cameraria ohridella on accumulation of proteins, peroxidase activity and composition in Aesculus hippocastanum leaves. Regulatory Mechanisms in Biosystems. 11 (2), 299-304.

Shupranova, L. V., Holoborodko, K. K., Seliutina, O. V., Pakhomov, O. Y. (2019). The influence of Cameraria ohridella (Lepidoptera, Gracillariidae) on the activity of the enzymatic antioxidant system of protection of the assimilating organs of Aesculus hippocastanum in an urbogenic environment. Biosyst. Divers., 2019, 27 (3), $238-243$.

Skuhravy, V. (1998). Zur Kenntnis der Blattminen-Motte Cameraria ohridella Deschka \& Dimic (Lep. Gracillaridae) an Aesculus hyppocastanum L. in der Tchechischen republiik. Ans fur Schadlingskunde Pflanz. Umweltschutz., $71,82-84$.

Straw, N., Bellet-Travers, M. (2004). Impact and management of the horsechestnut leaf-miner (Cameraria ohridella). Arboricultural Journal, 28, 67-83.

Szaboky, C., Vas, J. (1997). Ujabb adatok a Vadgesztenyelevel-Aknazo-Moryrol Cameraria ohridella Deschka \& Dimic 1986, Lep., Lithocolletidae. Novenyvedeiem., 33 (1), 29-33.

Tarwacki, G., Bystrowski, C., Celner-Warole, K. (2012). Effect of sun-exposure of the horse chestnut (Aesculus 
hippocasta-num L.) on the occurrence and number of parasitoids of the horse chestnut leafminer (Cameraria ohridella Deschka et Dimic) in central Poland in 20042006. Folia Forestalia Polonica, 54 (1), 56-62.

Zerova, M. D., Nikitenko, G. N., Narolskiy, N. B., Gershenzon, Z. S., Sviridov, S. V., Lukash, O. V., Babidorich, M. M., (2007).
Kashtanovaya miniruyushchaya mol' v Ukraine [Chestnut mining moth in Ukraine], Kiev, 90 (in Russian).

War, A. R., Taggar, G. K., Hussain, B., Taggar, M. S., Nair, R. M. \& Sharma, H. C. (2018). Plant defence against herbivory and insect adaptations. AoB PLANTS, 10(4). 